\title{
Cytogenetic differences between Peritelus familiaris and Centricnemus leucogrammus (Coleoptera: Curculionidae: Entiminae: Peritelini)
}

\author{
Dorota LACHOWSKA ${ }^{1}$, Maria ROŻEK ${ }^{1}$, Milada HOLECOVÁ ${ }^{2}$ and LuKasz KAJTOCH ${ }^{1}$ \\ ${ }^{1}$ Institute of Systematics and Evolution of Animals, Polish Academy of Science, Sławkowska 17, 31-016 Kraków, Poland; \\ e-mail: lachowska@isez.pan.krakow.pl \\ ${ }^{2}$ Department of Zoology, Comenius University, Mlynská dolina B-1, 842-15 Bratislava, Slovakia
}

Key words. Coleoptera, Curculionidae, chromosome number, C-banding, karyotype, NOR

\begin{abstract}
Differences in the karyology of two species, Centricnemus leucogrammus and Peritelus familiaris (Coleoptera: Curculionidae), were investigated in order to elucidate their taxonomic position of the taxa. Previously both species were placed in one genus whereas the latest taxonomic revision puts them in separate genera. Cytogenetic analysis of $P$. familiaris and $C$. leucogrammus showed significant differences in karyotype structure and confirmed their present taxonomic status. The diploid set of $C$. leucogrammus consists of 22 chromosomes with a fundamental number of arms (FN) of 45 and little variation in morphology and length. Peritelus familiaris has 24 chromosomes with FN of 47 and a more diverse karyotype. The karyotype evolution might have occured by centric fissions of autosomes. At pachytene and diplotene in spermatocytes, each chromosome bivalent showed a small band of pericentric heterochromatin. The bands were hardly visible or undetectable in other stages of spermatogenesis, namely mitotic metaphase, diakinesis, metaphase I and II. The nucleolar organizer regions (NORs) were active at premeiotic stages and early meiosis, but invisible at meiotic metaphase I, metaphase II, and mitotic metaphase. These results indicate the usefulness of cytogenetic methods in taxonomic evaluations.
\end{abstract}

\section{INTRODUCTION}

The tribe Peritelini includes species of weevil indigenous to the Southwestern Palaearctic, Nearctic and Ethiopian regions. Of the sixteen genera of Peritelini known from Europe, eleven occur in the Mediterranean area, and only five (Caenopsis Bach, 1854, Centricnemus Germar, 1827, Peritelus Germar, 1824 Simo Dejean, 1821 and Stomodes Schoenherr, 1826) inhabit Central Europe (Pierotti \& Bellò, 1997, 1998; Alonso-Zarazaga \& Lyal, 1999). Most species of Peritelini, either as adults and/or larva, are xerotermophilous and phytophagous, feeding on various plants. Numerous species are apterous, and nocturnal (Dieckmann, 1980; Hoffmann, 1950; Solari, 1955; Smreczyński, 1966). So far, only two species, Centricnemus leucogrammus Germar 1824 and Simo hirticornis (Herbst, 1795) have been examined karyologically (Suomalainen, 1954; Petryszak, 1977; Palm, 1995; Lachowska et al., 1999, 2004). The first species, Centricnemus leucogrammus, was originally described as Peritelus leucogrammus Germar, 1824, later transferred to the genus Ctenochirus by Seidlitz (1890) and subsequently classified as Peritelus (Ctenochirus) by Hoffmann (1950), Smreczyński (1966) and Dieckmann (1980). According to the latest taxonomic revision based on external morphology, this species belongs to the separate genus Centricnemus (Pierotti \& Bellò, 1998). Regarding Simo hirticornis, Suomalainen (1954) confirmed the existence of triploid and tetraploid populations of this parthenogenetic species in Switzerland. Palm (1995) found that the taxon "Simo hirticornis" sensu various European authors was a mixture of two species, S. hirticornis (Herbst, 1795) and S. variegatus (Boheman, 1843). Both of these species occur in Switzerland.

In the present study, differences in the karyology of two species of the tribe Peritelini from the family Curculionidae, Centricnemus leucogrammus (Germar 1824) and Peritelus familiaris Boheman, 1834, are described. The karyotype of $P$. familiaris is described and the differences between the species in terms of chromosome number, sex determination system, the course of meiosis, the relative length of chromosomes, C-band patterns, and localization of active NORs, are analysed. The chromosomal data are discussed in relation to the taxonomic classification of the species.

\section{MATERIAL AND METHODS}

For the cytogenetic study, adults of both sexes were collected in xerotherms of Poland and Slovakia in May and June 2004, 2005. Gonads were dissected under a stereomicroscope in several drops of hypotonic $0.9 \%$ sodium citrate solution containing $0.005 \%$ colchicine. The gonads were transferred into a small volume of the same solution and incubated for 45-60 $\mathrm{min}$ at room temperature. Then the gonads were fixed using to the method described by Rożek (1994) with minor modifications (Rożek \& Lachowska, 2001). C-banding was revealed using the procedure described by Sumner (1972) with some modifications. Briefly, the squashed preparations were treated with $0.3 \mathrm{~N} \mathrm{HCl}$ for $1 \mathrm{~min}$ at $20-23^{\circ} \mathrm{C}$, followed by thorough rinsing with distilled water and then air-dried. The slides were placed in a freshly prepared solution of $5 \%$ barium hydroxide at $20-23^{\circ} \mathrm{C}$ for 1-1.5 min. Next, they were rinsed with distilled water and incubated in $2 \times \mathrm{SSC}$ at $50^{\circ} \mathrm{C}$ for $1 \mathrm{~h}$ and again air-dried. Then the slides were stained with $4 \%$ Giemsa in phosphate buffer $(\mathrm{pH}$ 6.8) for 10 to $20 \mathrm{~min}$.

For the NOR silver staining, the method described by Howell $\&$ Black (1980) was used with some modifications. A brief outline of the technique is as follows. Two solutions, A and B (A a silver nitrate solution; $4 \mathrm{~g}$ of $\mathrm{AgNO}_{3}$ dissolved in $8 \mathrm{ml}$ of deionized water; B - a gelatin solution with formic acid; $1 \mathrm{~g}$ gelatin dissolved in $50 \mathrm{ml}$ distilled water, with stirring and gentle heating; after the gelatin dissolves, $0.5 \mathrm{ml}$ of formic acid is added), were prepared and mixed in a ratio of $2 \mathrm{~A}: 1 \mathrm{~B}$ on slides with squashed chromosomes. Then the slides were covered with a coverslip, placed into a dark humid box, and incubated at $50^{\circ} \mathrm{C}$ for $25 \mathrm{~min}$, at which time the mixture turns a 


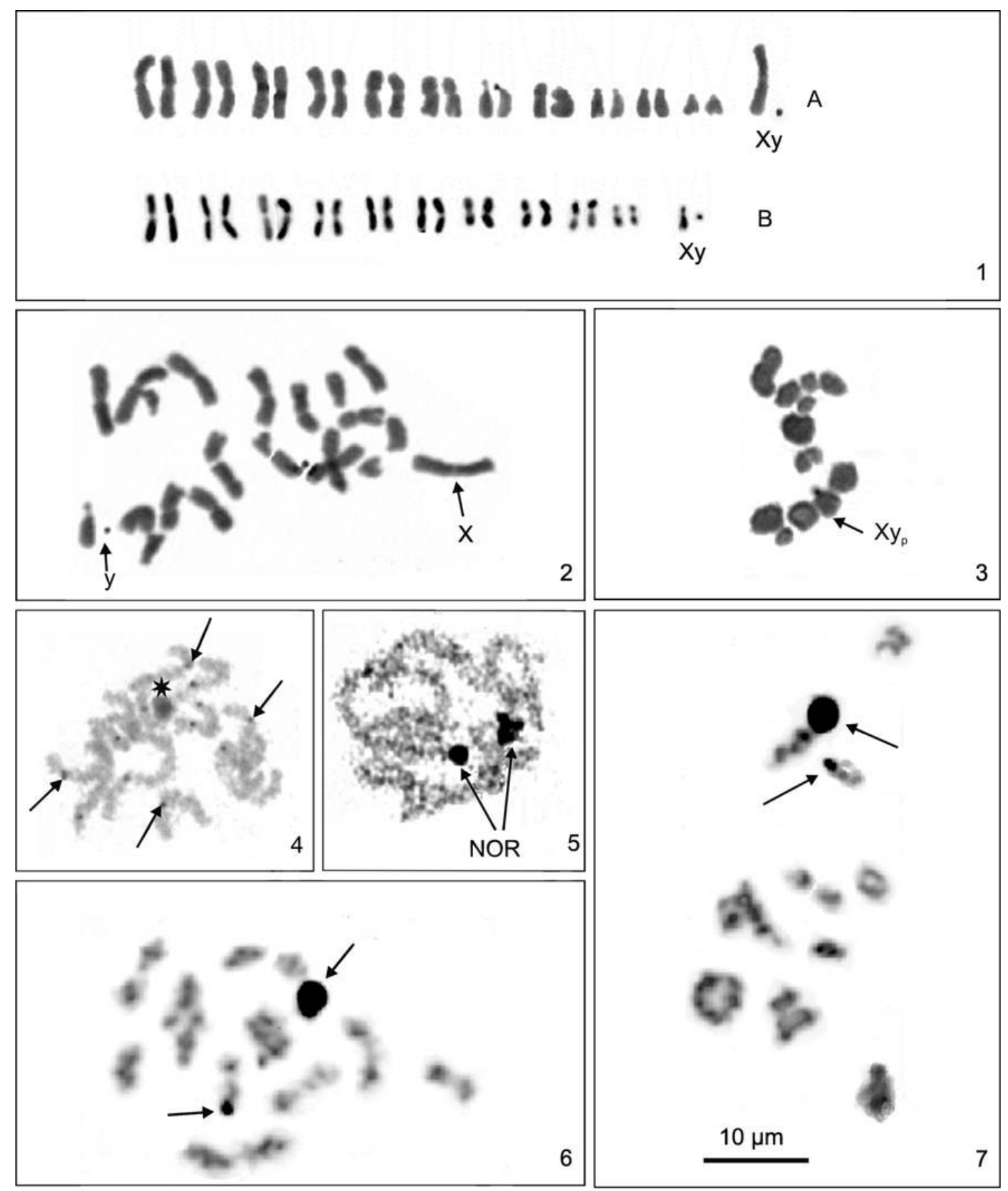

Figs 1-7: Mitotic and meiotic chromosomes of Peritelus familiaris and Centricnemus leucogrammus. 1A - karyotype of Peritelus familiaris and B - Centricnemus leucogrammus. Chromosomes stained with 4\% Giemsa in phosphate buffer after C-banding technique. 2 - male mitotic metaphase of $P$. familiaris with 24 chromosomes; arrows indicate the $\mathrm{X}$ and y sex chromosomes. 3 - male meiotic metaphase I of $P$. familiaris with 11 autosome bivalents and a heterovalent; arrow indicates the sex chromosomes of parachute type $\left(\mathrm{X}_{\mathrm{P}}\right) .4$ - male diplotene of $P$. familiaris; arrows indicate C-bands, asterisk indicates the heteropycnotic sex chromosomes. 5 - pachytene complement after silver staining with two active NORs in C. leucogrammus. 6 - male diakinesis of $P$. familiaris; arrows indicate two active NORs. 7 - male diakinesis of C. leucogrammus; arrows indicate two active NORs.

golden brown colour. The preparations were then rinsed with tap water, then distilled water, air-dried and mounted in Euparal. Chromosomes were classified according to Levan et al. (1964). Evaluation of chromosome morphology was based on ten mitotic metaphases (Table 1). Chromosome lengths were calculated as a percentage of total chromosome length of the haploid set (\% TCL), which also includes the sex chromosomes. Spermatogonial metaphase, meiotic stages and interphase nuclei were analyzed and photographed using a Nikon Eclipse 400 light microscope and a CCD DS-U1 camera (Nikon, Tokyo, Japan), and the software Lucia Image version 5.0 (Laboratory Imaging, Prague, Czech Republic).

\section{RESULTS}

Relative lengths and centromeric indexes of chromosomes are given in Table 1. The diploid complement of Peritelus famil- 
TABLE 1. Relative length (\% TCL) and centromeric index (AR) of particular chromosome pairs of Peritelus familiaris and Centricnemus leucogrammus.

\begin{tabular}{|c|c|c|c|c|}
\hline \multirow[t]{2}{*}{ Pair no. } & \multicolumn{2}{|c|}{$\begin{array}{c}\text { Peritelus familiaris } \\
2 \mathrm{n}=24, \mathrm{n} \widehat{\sigma}^{\hat{t}}=11+\mathrm{Xy}_{\mathrm{P}}\end{array}$} & \multicolumn{2}{|c|}{ 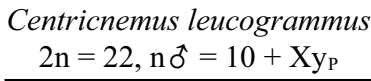 } \\
\hline & $\% \mathrm{TCL}$ & $\mathrm{AR}$ & $\%$ TCL AR & $\mathrm{AR}$ \\
\hline 1 & 10.92 & 1.25 & 12.57 & 1.43 \\
\hline 2 & 10.91 & 1.33 & 12.68 & 1.08 \\
\hline 3 & 10.52 & 1.27 & 11.75 & 1.17 \\
\hline 4 & 9.72 & 1.25 & 11.53 & 1.09 \\
\hline 5 & 8.27 & 1.24 & 9.35 & 1.26 \\
\hline 6 & 8.16 & 1.77 & 8.45 & 1.26 \\
\hline 7 & 7.62 & 3.72 & 8.05 & 1.24 \\
\hline 8 & 6.22 & 1.23 & 7.35 & 1.28 \\
\hline 9 & 5.41 & 3.29 & 6.78 & 1.60 \\
\hline 10 & 4.92 & 3.52 & 4.25 & 1.76 \\
\hline 11 & 3.02 & 7.21 & - & - \\
\hline $\mathrm{X}$ & 12.93 & 1.82 & 5.75 & 1.23 \\
\hline $\mathrm{y}$ & 1.92 & & 1.50 & \\
\hline
\end{tabular}

iaris males consisted of 22 autosomes and $\mathrm{X}$ and y sex chromosomes. The fundamental number of arms was $\mathrm{FN}=47$. The karyotype was asymmetric with 6 metacentric pairs of autosomes, one submetacentric pair, 3 subtelocentric pairs, and one acrocentric pair. The submetacentric X chromosome was the longest element in the set while the $\mathrm{y}$ chromosome was the smallest and dot like (Figs 1A, 2, 3) (Table 1). In meiotic prophase I, the sex chromosomes formed a parachute association $\left(\mathrm{Xy}_{\mathrm{p}}\right)$ and showed strong heteropycnosis (Fig. 4). Meiotic diakinesis was composed of large and medium size bivalents, five to seven rod-shaped, and one to two cross-like with one chiasma, three to five ring-shaped with two chiasmata, and $\mathrm{Xy}_{\mathrm{p}}$ (Fig. 6). The relative lengths of autosomes and heterochromosomes ranged from $12.93 \%$ to $1.92 \%$ (Table 1 ).

For Centricnemus leucogrammus, the chromosome number and meiotic behaviour is described by Petryszak (1977) and Lachowska et al. (1999, 2004). The diploid male complement consists of 20 autosomes and $\mathrm{X}$ and y sex chromosomes (Fig. 1B). The relative lengths of chromosomes ranged from $12.57 \%$ to $1.50 \%$ and the fundamental number of arms (FN) was 45 (Table 1).

The heterochromatin visualized by C-banding was found in the pericentromeric region of all autosomes and the $\mathrm{X}$ chromosome, while the $\mathrm{y}$ chromosome was completely heterochromatic. In $P$. familiaris and $C$. leucogrammus, all the chromosomes obtained from male germ cells showed heavily stained but small heterochromatin segments visible during pachytene and diplotene (Fig. 4) and hardly visible or undetectable during the mitotic metaphase (Figs 1 and 2), diakinesis (not shown), metaphase I (Fig. 3) and metaphase II (not shown).

Males of both species exhibited the same pattern of silver precipitation during the cell cycle. During meiotic stages two Agpositive nucleoli could be recognized at early prophase but faded rapidly during middle prophase and disappeared completely by late prophase. In mitotic metaphase plates, the silverimpregnated blocks became invisible. One NOR was located in an autosome pair, the other NOR in the sex chromosomes (Figs $5-7)$.

\section{DISCUSSION}

Cytogenetic methods have become a widespread and powerful tool for the delineation and identification of many insects, particularly in groups, in which species might be morphologically cryptic. Species-specific karyotypes, defined by chromosome number, size, morphology and sex chromosomes are usually constant and can be considered a definite character for taxonomic purposes. The value of karyotype for taxonomy and phylogenetic relationships has been demonstrated in many beetle species, e.g. Carabidae, Chrysomelidae, and Curculionidae (Serrano, 1986; Petitpierre, 1997; Rożek et al., 2004). The cytogenetic differences between the two species examined are chromosome number and morphology of the karyotypes. The diploid complement of Centricnemus leucogrammus consists of 22 chromosomes with little variation in morphology and length of autosomes. Karyotypes with a prevalence of meta- and submetacentric chromosomes are the rule in the karyotypic architecture of curculionids (Lachowska et al., 1998). The second species, Peritelus familiaris, possesses 24 chromosomes, and the karyotype is more diverse and asymmetric with a very wide array of sizes from the small dot-like y chromosome to the large X chromosome. The course of meiosis in both species is similar. The metaphase I plates consist of 10 autosomal bivalents in C. leucogrammus or 11 autosomal bivalents in P. familiaris, respectively, and the sex chromosomes form a typical parachute. The parachute association $\left(\mathrm{Xy}_{\mathrm{p}}\right)$ of the large $\mathrm{X}$ and small y chromosomes is characteristic for many coleopterans (Smith \& Virkki, 1978). It can be concluded from all available data that the diploid chromosome number $2 \mathrm{n}=22$ is characteristic for weevils, occurring in $34 \%$ of species examined karyologically and seems to be ancestral for Curculionidae as a whole. Therefore, the karyotype evolution in P. familiaris might occur by centric fission of autosomes, because such rearrangements would increase the chromosome number and change chromosome morphology. In this sense, the diploid complement of $P$. familiaris is strikingly distinct from that of $C$. leucogrammus and the majority of weevils. C-banding pattern on chromosomes of $C$. leucogrammus and $P$. familiaris shows a small amount of heterochromatin as dots located around centromeres. The karyotypes of many examined members of the family Curculionidae, described from gonial cells, are characterized by a small proportion of heterochromatin, located mainly in a centromeric position (Holecová et al., 2002; Rożek et al., 2004; Lachowska et al., 2005).

Cytogenetic analysis of Peritelus familiaris and Centricnemus leucogrammus showed significant differences in karyotype structure and confirmed their present taxonomic affiliation to two separate genera (Pierotti \& Bellò, 1998; Alonso-Zarazaga \& Lyal, 1999). Currently, the chromosome number in conservative groups, such as the Entiminae subfamily (having the ancestral karyotype), is a very important attribute. Recent phylogenetic and evolutionary studies of beetles mainly rely on DNA analysis (Gómez-Zurita \& Galián, 2005). In the future, mtDNA markers may provide additional information about the genetic relationship of both genera.

ACKNOWLEDGEMENTS. We are grateful to M. Mazur (Pedagogical University in Cracow) for providing specimens of Centricnemus leucogrammus, to F. Marec and two anonymous reviewers for their encouragement and suggestions for improving this work. This research was supported by Ministry of Science and Information Society Technologies, Poland, Project No. 3P04C 085 to D. Lachowska and by the Scientific Grant Agency of the Ministry of Education and the Slovak Academy of Sciences, grant number 1/3277/06 to M. Holecová. 


\section{REFERENCES}

Alonso-Zarazaga M.A. \& Lyal C.H.C. 1999: A World Catalogue of Families and Genera of Curculionoidea (Insecta: Coleoptera). (Excepting Scolytidae and Platypodidae). Entomopraxis, S.C.P, Barcelona, 315 pp.

DiECKMANN L. 1980: Beiträge zur Insektenfauna der DDR: Coleoptera - Curculionidae (Brachycerinae, Otiorhynchinae, Brachyderinae). Beitr. Entomol. (Berlin) 30: 145-310.

Germar E.F. 1827: Centricnemus. In Ersch J.S. \& Gruber J.G. (eds): Allgemeine Encyclopädie der Wissenschaften und Künste, $46 \mathrm{pp}$.

GómeZ-ZuRita J. \& Galián J. 2005: Current knowledge on genes and genomes of phytophagous beetles (Coleoptera: Chrysomeloidea, Curculionoidea): a review. Eur. J. Entomol. 102: $577-597$.

Hoffmann A. 1950: Coléoptères Curculionides (Première Partie). Faune de France 52. Lechevalier, Paris, 486 pp.

Holecová M., RożeK M. \& LachowsKa D. 2002: Heterochromatic banding patterns on chromosomes of twelve weevil species (Insecta, Coleoptera, Curculionoidea: Apionidae, Curculionidae). Folia Biol. (Kraków) 50: 129-134.

Howell W. \& BlaCK D.A. 1980: Controlled silver-staining of nucleolus organizer regions with protective colloidal developer: a 1-step method. Experientia 36: 1014-1015.

Lachowska D., Rożek M. \& HolecovÁ M. 1998: Karyotypic data on weevils (Coleoptera, Curculionidae). Folia Biol. (Kraków) 46: 129-136.

Lachowska D., Holecová M. \& RożeK M. 1999: Karyological studies on six bisexual weevil species (Coleoptera, Curculionidae). Folia Biol. (Kraków) 47: 105-110.

Lachowska D., Holecová M. \& Rożek M. 2004: Notes on chromosome numbers and C-banding patterns in karyotypes of some weevils from Central Europe (Coleoptera, Curculionoidea: Apionidae, Nanophyidae, Curculionidae). Folia Biol. (Kraków) 52: 61-66.

Lachowska D., Holecová M. \& RożeK M. 2005: C-banding karyotype and NORs analyse in eight species of Barypeithes Duval from Central Europe (Coleoptera, Curculionidae, Entiminae). Caryologia 58: 274-280.

Levan A., Fredga K. \& Sonberg A.: 1964: Nomenclature for centromeric position on chromosomes. Hereditas 52: 201-220.

PALM E. 1995: The North European species of Simo Dejean, 1821 (Coleoptera, Curculionidae). Entomol. Meddr. 63: 109-113.

Petitpierre E. 1997: The value of cytogenetics for the taxonomy and evolution of leaf beetles (Coleoptera, Chrysomelidae). Misc. Zool. 20: 9-18.
Petryszak B. 1977: A karyological study of five bisexual species of weevils (Curculionidae, Coleoptera). Zool. Polon. 26: 475-482.

Pierotti H. \& Bellò C. 1997: Contributi al riordinamenti sistematico dei Peritelini palearctici. I. Istituzione di tre nuovi generi e descrizione di una nuova specie (Coleoptera, Curculionidae). Boll. Mus. Reg. Sci. Nat. Torino 15: 157-177.

Pierotti H. \& Bellò C. 1998: Present knowledge of Palaearctic Peritelini (Coleoptera: Curculionidae: Polydrosinae). In Colonnelli E., Louw S. \& Osella G. (eds): Taxonomy, Ecology and Distribution of Curculionoidea (Coleoptera: Polyphaga). Proceedings of XX International Congress of Entomology. Atti del Museo Regionale di Scienze Naturali, Torino, pp. 81-108.

RożEK M. 1994: A new chromosome preparation technique for Coleoptera (Insecta). Chromosome Res. 2: 76-78.

RożEK M. \& LACHOWSKa D. 2001: C-bands on chromosomes of four beetle species (Coleoptera: Carabidae, Silphidae, Elateridae, Scarabaeidae). Folia Biol. (Kraków) 49: 179-182.

Rożek M., Lachowska D., Petitpierre E. \& Holecová M. 2004: C-bands on chromosomes of 32 beetle species (Coleoptera: Elateridae, Cantharidae, Oedemeridae, Cerambycidae, Anthicidae, Chrysomelidae, Attelabidae and Curculionidae). Hereditas 140: 161-170.

Seiduitz G. 1890: Fauna Baltica. Die Käfer (Coleoptera) der Deutschen Ostprovinzen Russlands. Zweite neu bearbeite Auflage. Hartungsche Verlagsdrukerei, Königsberg, 578 pp.

SERRANO J. 1986: Karyotypical approach to carabid evolution (Coleoptera). In Erwin T.L., Ball G.E. \& Whitehead D.R. (eds): Carabid Beetles. G. Fischer, Stuttgard, New York, pp. 221-225.

Smith S.G \& Virkki N. 1978: Animal Cytogenetics. 3. Insecta. 5. Coleoptera. Gebrüder Borntraeger, Berlin, $366 \mathrm{pp}$.

SMRECZYŃSKi S. 1966: Weevils - Curculionidae. Subfamilies Otiorhynchinae, Brachyderinae. Keys for identification of Polish insects. PWN, Warszawa, 130 pp. [in Polish].

Solari F. 1955: Proposta di un riordinamento delle tribù degli Otiorhynchini e dei Peritelini e creazione di tre nuovi generi di questi ultimi (Col. Curculionidae). Mem. Soc. Entomol. Ital. 33: 33-63.

SumNer A. 1972: A simple technique for demonstrating centromeric heterochromatin. Exp. Cell. Res. 75: 304-306.

SuOMALAINEN E. 1954: Zur Zytologie der parthenogenetischen Curculioniden der Schweiz. Chromosoma 6: 627-655.

Received February 2, 2006; revised and accepted March 6, 2006 